\title{
オペレータのための簡易型人間工学チェックリストの作成
}

\author{
O楠神 健，宇賀神 博，藤浪浩平（鉄道総合技術研究所）
}

\section{Introduction of a human interface checklist for system operators in large-scale industries} Ken Kusukami, Hiroshi Ugajin, Kohei Fujinami(Railway Technical Research Institute)

\section{1.はじめに}

産業界では自動化システムの導入が進められてい るが、それが有効かつ安全に機能するためには、設 計時におけるヒューマンファクタ面での検郡が欠か せないっこれついては human-centered principles など、人間・機械間の関係を良好に保つための設計 理念が様々な分野で提唱されている。

今回われわれは、それらの理念を具体化するため の事柄を体系的に収集整理し、表現を容易化した上 で、比較的規模の大きい自動化システム評価のため のチェックリストとしてまとめた。

その目的は以下の通りである。まず、設計に際し、 個々のシステムごとの詳細なチェックリストに加え、 システム全体からみたヒューマンファクタ上の健全 度が容易に評定できるツールが必要と考えられるこ とである。次に、実際にシステムを使用し、その使 い勝手について最も影響を受けるオペレータ等のユ 一ザが、使いやすさを実現するためのポイントを体 系的に理解しておくことが必要と考えるからである。

以下にチェックリストの概要を説明する。

\section{2. 項目の作成方法}

航空機や原子カプラントなどの自動化の進んだ大 規模システムの設計要件、コンピュータ・インタフ ェースのガイドライン、人間工学や認知工学の機能 配分やインタフェースに関する研究知見等、主に文 献調査をもとに項目を作成した。

\section{3. チェックリストの基本的な体系}

まず第 1 章「システムの性格」で自分のシステム の特徴を理解した上で、第2 章「自動化と機能配分〕 および第 3 章「インタフェース」でシステムの具体 的な評価を行う構成とした。項目数は全部で 149 で ある。表 1 にチェックリストの構成と内容別の項目 数を記した。

次に、チェックリストの基礎になる基本的な体系 について説明する。
「システムの性格」では、システムとしての特徵 と、それを反映したオペレータの職務特性とを把握 するための項目を用意した。

「自動化と機能配分」の内容は大きく 3 つに区分 される。まず、システムの自動化は、オペレータの 主体的なコントロールをなくすと同時にシステム自 身が自動的に制御を行うため、オペレータの状況認 識力を低下させるといわれる。この問題に対する方 策として、状況のわかりやすさ、フィードバック、 システム支配感等の観点から項目を用意した。

次に、自動化は一般に平常時の人間の役割をシス テムの制御者から監視者へとシフトさせるとされる。 これに伴う問題点として、定常時における適切な負 荷、オペレータのやりがい等について評価する。

最後に、自動化は、異常時の負荷を高めるととも に、作業自身を難しくするといわれる。これについ て、作業自身の容易さ、対処方法のわかりやすさ、 支援システムなどの項目を用意した。

「インタフェース」の改善は、オペレータのワー クロードを減らす、オペレータのエラーを防ぐ等の メリットがあるとされる。これらの点について、イ ンタフェースの自然さ、情報表示のわかりやすさ、 警報システムの適切さ、ヒューマンエラー対策の充 実度等の観点から評価するようにした。

4. 評価方法

第 1 章では項目の該当度を、第 $2 、 3$ 章では、項 目の該当度と重要度を評定するようにし、該当度は 7 段階、重要度は6 段階評定とした。該当度は、そ の項目についての達成度と読み変えることができる。 また、重要度が高く該当度の低い項目は、改善点を 示していると考えられる。

5. 予備的評価

チェックリストの評価を行うため、日本の代表的 な 9 種のシステム・オペレータ (鉄道・道路・航空 
I．システムの性格(40)

1. システムの特性と自動化レベル(20)

(1)人の制御と物の制御 (2)制御と操作 (3)他組織との関連

(4)自動制御、遠隔制御、集中制御

(5)異常や事故の発生原因

(6人間と機械の役割分担

2. オペレータの職務特性(20)

(1)オペレータの主要な使命や役割

(2)注意すべきヒューマンエラー

(3)オペレータに必要とされる心身機能

II. 自動化と機能配分(54)

1. 状況やシステムの仕組のわかりやすさ(5)

(1)状況のわかりやすさ

(2)システムの仕組のかかりやすさ

2. システムからのフィードバックの適切さ(2)

3. システム支配感の保持(9)

(1) 状況認識力の保持

(2)システムがカバーできる範囲の認識

(3)オペレータの主体性の高さ

4. 定常時における適切な負荷と監視業務の除去(6)

(1)定常時における負荷の適切さ

(2)不適切な監視業務の除去

5. 異常時対応の容易さ、わかりや寸さ(12)

(1)異常の適切な通知と作業負荷の軽减

(2)異常の際の状㫛・対処方法のかかりやすさ

(3)異常時対応の容易さ・䉍単さ

(4)システムの異常時対応能力の高さ

6. システムからの人間への支援(6)

(1)支援方法の豊富さ・多様さ
(2)支援機能の使いやすさ・充実度

7. 高負荷時の作業負荷緩和嘰能の高さ(3)

8. オペレータのやりがいの良好さ(4)

9. 自動化機能の適正な進化(7)

III. インタフェース(55)

1.インタフェースの自然さ、わかりやすさ(10)

(1)表示や操作形態の統一

(2)自然な対応づけ、レイアウトの工夫

(3)直観的なかかりやすさ・自然さ

(4)類似した事柄の利用

2. 情報表示のわかりやすさ、情報制御の適切さ(9)

(1)個々の情報の表示内容や表示形態の適切さ

(2情報の表示量や表示速度の適切さ

（3情報表示の工夫、意味のわかりやすさ

3. 適切なモード設定、情報検索のしやすさ (7)

(1)適切なモート設定

(2)情報検索のしやすさ、かかりやすさ

4. システムからの警報の適切さ(8)

(1)個々の警報の適切さ

(2)警報システム全体としての適切さ

5. 操作譏器のインタフェースの適切さ (4)

(1操作形態や機器の応答の適切さ

(2)品作感覚のリアルさ

6. システムのヒューマンエラー対策の充実度(8)

(1)操作前の確㒛機能や操作方法の工夫

(2)エラーの検知および通知嘰能

(3やりなおしや処理中止の容易さ

(4)エラーのバックアップや影響緩和機能

7. インタフェースや自動化レベル変更の柔軟さ (2)

8. オペレータ間のインタフェースの適切さ(7)

注）各行の末尾の数值は、その事柄に属する項目数である。

の指令・管制担当者、化学・石油・電力のプラント ・ オペレータ、新幹線運転士・パイロット・外航船舶 操縦士の交通関係オペレータ）に自らの扱うシステ ムを対象にチェックリストへの評定を依頼した。

調查結果は現在分析中であるが、項目の中でシス テムを問わず共通に重視される事柄やシステムの性 格が反映されやすい分野などが明らかになると考え られる。評定がばらついた場合には、当チェックリ ストによる診断の際の外部基準は特に用意せず、結 果は評定者に主体的に解釈してもらうのが適当では ないかと考えている。

\section{6. おわりに}

チェックリストはソフトウェア化を図り、診断結 果に基づく改善ポイントの出力とともに、事柄ごと の解説が表示されるようにし、オペレータに対する 教育ツールとしての配慮も行った。

しかし、一方で予備調査のコメントからは、自分 のシステムに馿染まない項目やわかりにくい表現の 項目があることも指摘された。また、内容的には、 アフォーダンスのように、ユーザに評定を求めるこ と自身に困難のある項目も含まれている。これらの 点の改良を今後進めたい。 